\title{
Cytogenetic abnormalities and fragile-x syndrome in Autism Spectrum Disorder Kavita S Reddy*
}

Address: Genzyme Genetics, Orange CA 92868, USA

Email: Kavita S Reddy* - kavita.reddy@gmail.com

* Corresponding author

Published: 18 January 2005

BMC Medical Genetics 2005, 6:3 doi:10.1 186/147/-2350-6-3
Received: 08 August 2004

Accepted: 18 January 2005

This article is available from: http://www.biomedcentral.com/I47I-2350/6/3

(C) 2005 Reddy; licensee BioMed Central Ltd.

This is an Open Access article distributed under the terms of the Creative Commons Attribution License (http://creativecommons.org/licenses/by/2.0), which permits unrestricted use, distribution, and reproduction in any medium, provided the original work is properly cited.

\begin{abstract}
Background: Autism is a behavioral disorder with impaired social interaction, communication, and repetitive and stereotypic behaviors. About 5-10\% of individuals with autism have 'secondary' autism in which an environmental agent, chromosome abnormality, or single gene disorder can be identified. Ninety percent have idiopathic autism and a major gene has not yet been identified. We have assessed the incidence of chromosome abnormalities and Fragile $X$ syndrome in a population of autistic patients referred to our laboratory.
\end{abstract}

Methods: Data was analyzed from 433 patients with autistic traits tested using chromosome analysis and/or fluorescence in situ hybridization (FISH) and/or molecular testing for fragile $X$ syndrome by Southern and PCR methods.

Results: The median age was 4 years. Sex ratio was 4.5 males to I female [354:79]. A chromosome (cs) abnormality was found in $14 / 42 \mid$ [3.33 \%] cases. The aberrations were: 4/14 [28\%] supernumerary markers; 4/I4 [28\%] deletions; I/I4 [7\%] duplication; 3/I4 [2I\%] inversions; 2/I4 [14\%] translocations. FISH was performed on 23 cases for reasons other than to characterize a previously identified cytogenetic abnormality. All 23 cases were negative.

Fragile-X testing by Southern blots and PCR analysis found 7/316 [2.2 \%] with an abnormal result. The mutations detected were: a full mutation (fM) and abnormal methylation in 3 [43\%], mosaic mutations with partial methylation of variable clinical significance in 3 [43\%] and a permutation carrier [14\%].

The frequency of chromosome and fragile- $X$ abnormalities appears to be within the range in reported surveys (cs $4.8-1.7 \%$, FRAX 2-4\%). Limitations of our retrospective study include paucity of behavioral diagnostic information, and a specific clinical criterion for testing.

Conclusions: Twenty-eight percent of chromosome abnormalities detected in our study were subtle; therefore a high resolution cytogenetic study with a scrutiny of $15 q|1.2 q| 3,2 q 37$ and Xp23.3 region should be standard practice when the indication is autism. The higher incidence of mosaic fragile- $X$ mutations with partial methylation compared to FRAXA positive population $[50 \%$ vs $15-40 \%$ ] suggests that faint bands and variations in the Southern band pattern may occur in autistic patients. 


\section{Background}

In 1943 Kanner coined "infantile autism" (autism derived from Greek autos, or self) after observing 11 children, mostly boys, on the basis of their social isolation. Autism, often referred to as autistic disorder or infantile autism, is a complex behavioral disorder, which, by definition, develops prior to age three. Autism is defined completely on the basis of impairments in social interaction and communication, repetitive and stereotypic behaviors. Recent research has examined autistic traits in a population of twins and found that social impairment actually follows a unimodal distribution without a clear demarcation to separate cases of the disorder [1]. For this reason, future discussion of autism may be referred to as autism spectrum disorder (ASD) [2].

For most children, the onset of autism is gradual; however, about $30 \%$ have a "regressive" onset. Fifty to seventy percent of children with autism are defined as mentally retarded by nonverbal IQ testing. Seizures develop in about $25 \%$ of children with autism. About $25 \%$ of children who fit the diagnostic criteria for autism at age two or three years subsequently begin to talk and communicate, and by six or seven years blend to varying degrees into the regular school population. The remaining 75\% continue to have a life-long disability requiring intensive parental, school, and societal support. There are no biologic markers, therefore the standard criteria, compiled by the American Psychiatric Association Manual of Psychiatric Diseases, 4th edition (DSM-IV), is the primary diagnostic reference used in the United States for autism. The causes of autism can be divided into "idiopathic," which comprises the majority of cases, and "secondary," in which an environmental agent, chromosome abnormality, or single gene disorder can be identified. About 5$10 \%$ of individuals with autism can be diagnosed with secondary autism; the remaining $90-95 \%$ have idiopathic autism. About $30 \%$ of children with idiopathic autism have complex autism, defined by the presence of dysmorphic features or microcephaly or a structural brain malformation [3]. About $70 \%$ of children with idiopathic autism have essential autism, defined as the absence of physical abnormalities.

A recent CDC case-finding study in Brick Township, New Jersey reported prevalence at 40 per 10,000 for autism [4]. While the latest epidemiologic study from the United Kingdom utilizing specialized visiting nurses who monitored child health and development at seven months, 18 to 24 months, and three years of age reported a prevalence rate of 16.8 per 10,000 for autism [5]. The sex ratio for autism has been estimated at 4 males: 1 female $[6,7]$.

Social cognition and communication in autism may be related to dysfunction in the amygdala, hippocampus, and related limbic and cortical structures. The cerebellum may also form part of a distributed neuronal network responsible for social cognition and communication. Serotonin is the neurotransmitter implicated in autism [8]

The single gene disorders in which secondary autism is observed include fragile $\mathrm{X}$ syndrome, tuberous sclerosis, phenylketonuria, Rett syndrome [3,9], Sotos, Neurofibromatosis I, Joubert syndrome [10], and Smith-LemliOpitz syndrome [11]. Risk to sibs of idiopathic cases is 75 times greater than the prevalence in the general population [7] and higher concordance for autism among monozygotic $(60-90 \%)$ than dizygotic $(0-10 \%)$ twins [12] argue for a genetic predisposition to idiopathic autism. Multiple independent whole genome scans and chromosomal abnormalities studies have pointed out several candidate regions on chromosomes $2 \mathrm{q}, 3 \mathrm{q}, 7 \mathrm{q}, 6$, $13 q, 15 q, 16 p, 17 q$ and sex chromosomes. These regions possess candidate genes that have been screened for mutations or association with autism [13]. However, a clear involvement of a major susceptibility gene (or genes) in autism remains far from clear. The results from linkage studies and the drop in the concordance rates between monozygotic and dizygotic twins suggests that the genetic etiology of autism is certainly heterogeneous (different genes in different families), polygenic (more than one affected gene per individual) with epigenetic influences and allelic heterogeneity (different variants in the same gene may lead to different patterns of genetic disease) [13$15]$.

To gain further insight into secondary autism we have compiled data on patients with autistic traits tested for fragile-X syndrome using molecular methods and chromosome abnormalities using cytogenetic analysis and FISH.

\section{Methods}

A search was initiated using the key word autism in the indication field of the Genzyme Genetics, Orange laboratory database. For each case the electronic data and/or files were reviewed. The referral center, age, sex, karyotype, fluorescence in situ hybridization (FISH) and fragile $\mathrm{X}$ results were extracted and tabulated.

Table I: Demographics of the ASD patients tested

\section{Demographics}

Patients with ASD referred for genetic testing $=433$

Median age $=4$ years

Sex ratio $=4.5$ males to $\mathrm{I}$ female 
Table 2: The chromosome abnormality found in $3.33 \%$ (14/42I) patients with an indication of autism

\begin{tabular}{|c|c|c|c|c|c|c|}
\hline SI \# & Age & Sex & Clinical Indication & Chromosome Result & FISH Result & $\begin{array}{l}\text { Fragile } \\
\text { X Result }\end{array}$ \\
\hline & & & & Marker $4 / 14=28 \%$ & & \\
\hline 1 & 6.1 & M & Autism & $47, X Y,+\operatorname{mar}[27] / 46, X Y[3]$ & .ish $\operatorname{der}(2)(\mathrm{D} 2 Z+)$ & NRM \\
\hline 2 & 5 & $\mathrm{~F}$ & Autism & $47, \mathrm{XX},+$ mar & $\begin{array}{l}. \text { ish } \operatorname{der}(15)(D \mid 5 Z+, D I 5 S I I++ \\
\text { GABRB3+) }\end{array}$ & NT \\
\hline 3 & 3 & M & Autism & $47, X Y,+$ mar de novo & $\begin{array}{l}. i s h \\
i(15)(q \mid I .2)(\text { rRNA++,DI5Z+,DI5SII-) }\end{array}$ & NT \\
\hline 4 & 5.1 & $\mathrm{~F}$ & Autism, MR & $\operatorname{mos} 47, X Y,+r[15] / 46, X X[15]$ & $\begin{array}{l}\text { der(I5)(rRNA+,DI5Z+,DI5SII+,GABR } \\
\text { B3+). }\end{array}$ & NT \\
\hline
\end{tabular}

\begin{tabular}{|c|c|c|c|c|c|c|}
\hline & & & & Duplication $1 / 14=7 \%$ & & \\
\hline 5 & $\begin{array}{l}16.7 \\
5\end{array}$ & $\mathrm{~F}$ & Autism & $46, X X$,dup $(\mid 5)(q|| .2 q \mid 3)$ de novo & $\begin{array}{l}\text { ish } \\
\text { dup }(\mid 5)(q \mid 2)(D|5 S| I++, G A B R B 3++) d e \\
\text { novo }\end{array}$ & NT \\
\hline
\end{tabular}

\begin{tabular}{|c|c|c|c|c|c|c|}
\hline & & & & Deletion $4 / 14=28 \%$ & & \\
\hline 6 & 6.5 & $\mathrm{~F}$ & $\begin{array}{l}\text { Autism, DD, MR, } \\
\text { macrocephaly }\end{array}$ & & .ish del(2) (q37.3)(D2S447-) & NT \\
\hline 7 & 6.6 & $\mathrm{~F}$ & Autism, DD & $46, X X, \operatorname{del}(3)(p 25)$ de novo & & NT \\
\hline 8 & 11.7 & M & $\begin{array}{l}\text { Autism, DD, MR, multiple } \\
\text { congenital abnormality, h/o DS }\end{array}$ & $46, X Y, \operatorname{del}(I 2)(q 21.2 q 23.3)$ & .ish $12(w c p \mid 2 \times 2)$ & NRM \\
\hline \multirow[t]{2}{*}{9} & 3.6 & M & Autism & $46, X Y$,del(I3)(q|3.2q|4.I)de novo & .ish $|3 q| 3(D \mid 3 S 6 \times 2),|3 q| 4(R B \times 2)$ & NT \\
\hline & & & & Inversion $3 / 14=21 \%$ & & \\
\hline 10 & 2.8 & $\mathrm{~F}$ & Autism & $46, X X, \operatorname{inv}(10)(p|| .2 q 21.2)^{*}$ & NT & NRM \\
\hline II & 3.5 & M & Autism & $\begin{array}{l}\text { Mos46,XY,inv(I4)(q II.2q33)[3]/ } \\
46, X Y[I 7]^{*}\end{array}$ & NT & NRM \\
\hline \multirow[t]{2}{*}{12} & 3.25 & M & Autism, hypotonia, DD & $\begin{array}{l}46, X Y, \text { add }(17)(q 23) \text { or } \\
\text { inv(17)(q23q25)de novo }\end{array}$ & $\begin{array}{l}\text { ish } \\
\operatorname{inv}(\mid 7)(q 24.2 q 25.3)(\text { wcp } 17 \times 2, M P O \times 2, D \\
\text { I SS928×2) }\end{array}$ & NT \\
\hline & & & & Translocation $2 / 14=14 \%$ & & \\
\hline 13 & 2.7 & $\mathrm{~F}$ & Autism & $46, X X, t(1 ; 14)(q 25 ; q 31.2)$ & NT & NT \\
\hline 14 & 3.3 & M & Autism & $46, X Y, \operatorname{der}(14 ; 18)(q 10 ; q 10)$ & NT & NRM \\
\hline
\end{tabular}

$\mathrm{DD}=$ developmental delay, $M R=$ mental retardation, $\mathrm{DS}=$ Down syndrome, $N T=$ not tested $N R M=$ normal $*_{\text {inv }}(I 0)$ is a normal familial variant and $\operatorname{inv}(14)$ is a frequently observed artifact of culture

G-banded metaphases were prepared using standard procedures and FISH was performed using the protocol provided by the manufacturer of the commercial probes (Vysis Inc., Illinois, MI).

Fragile X test: Isolated DNA was tested by both Southern blot analysis and Polymerase chain reaction (PCR) for the size and methylation status of the CGG repeat expansion within the FMR-1 gene. Southern blot analysis was performed with the probe StB12.3 on EcoR1 and Eag1 digested DNA. PCR products were separated by acryla- mide gel electrophoresis and detected with a CGG repeat probe.

\section{Results}

Patients with autistic traits were referred by physicians to our laboratory for genetic testing. The clinical diagnostic criteria applied were not specified on the test request forms.

A total of 433 patients with an indication of autism were sent to our laboratory for genetic diagnosis. The median 
Table 3: Summary of FISH cases

\begin{tabular}{|c|c|c|c|c|c|c|}
\hline SI \# & $\begin{array}{r}\text { Age in } \\
\text { years }\end{array}$ & Sex & Clinical Indication & Karyotype & FISH & FRAX \\
\hline 1 & 5.25 & M & Autism & $46, X Y$ & Normal ish 7ql I.23(ELNX2) & \\
\hline 2 & 7 & M & Autism, FTT, MR, DD & $46, X Y$ & Normal ish 7ql I.23(ELNX2) & NRM \\
\hline 3 & & M & Autism & $46, X Y$ & Normal ish 7ql I.23(ELNX2) & NRM \\
\hline 4 & 3.6 & M & Autism, DD, hypocalcemia, cardiac defect, MR & $46, X Y$ & Normal ish $22 q 11.2(T U P L E x 2)$ & \\
\hline 5 & 6.3 & M & Autism, DD, hypotonia & $46, X Y$ & Normal ish 22q II.2(TUPLEx2) & \\
\hline 6 & 3.5 & M & Autism & not ordered & Normal-ish 22q I I.2(TUPLEx2) & \\
\hline 7 & & M & Autism & $46, X Y$ & Normal-ish 22q I I.2(TUPLEx2) & \\
\hline 8 & & $M$ & Autism & $46, X Y$ & Normal-ish 22q I I.2(TUPLEx2) & NRM \\
\hline 9 & 6.5 & M & Autism, DD, MR & $46, X Y$ & Normal, ish $15 q \mid 2(D|5 S| \mid \times 2)$ & NRM \\
\hline 10 & 11.6 & $M$ & Autism, DD & $46, X Y$ & Normal, ish $15 q \mid 2(D|5 S| \mid \times 2)$ & NRM \\
\hline 11 & 3.5 & $M$ & Autism & $46, X Y$ & Normal, ish $15 q \mid 2(D|5 S| \mid \times 2)$ & NRM \\
\hline 12 & 3 & M & Autism & $46, X Y$ & Normal, ish $15 q \mid 2(D|5 S| \mid \times 2)$ & \\
\hline 13 & 2 & $M$ & Autism, DD,MR & $46, X Y$ & Normal-ish I5qI2(DI5SIIx2) & NRM \\
\hline 14 & 2.5 & $\mathrm{~F}$ & Autism, DD,MR & $46, X X$ & Normal ish I5qI2(DI5SII) & NRM \\
\hline 15 & 3.6 & M & Autism, DD, patch hyperpigmentation & $46, X Y$ & Normal, ish $15 q \mid 2(D|5 S| \mid \times 2)$ & NRM \\
\hline 16 & 3.5 & M & Autism, DD, seizures & $46, X Y$ & Normal- subtelomere panel & NRM \\
\hline 17 & 3.5 & $\mathrm{~F}$ & Autism, DD & $46, X X$ & Normal-subtelomeres & NRM \\
\hline 18 & 4.6 & $M$ & Autism, DD & $46, X Y$ & Normal-subtelomeres & NRM \\
\hline 19 & 8.6 & M & Autism, DD & $46, X Y$ & Normal-subtelomeres & NRM \\
\hline 20 & & M & Autism & $46, X Y$ & Normal-subtelomeres & NRM \\
\hline 21 & 2.7 & M & Autism & $46, X Y$ & Normal-subtelomeres & $\mathrm{ABN}$ \\
\hline 22 & 16 & M & Autism, DD, dysmorphic features, MR & $46, X Y$ & $\begin{array}{l}\text { Normal, subtelomeres Normal, ish } \\
|5 q| 2(D|5 S| \mid \times 2)\end{array}$ & \\
\hline 23 & 17.5 & $\mathrm{~F}$ & Autism & $46, X X$ & $\begin{array}{l}\text { Normal ish }|5 q||.2 q| 3(D|5 S| \mid \times 2) \\
|7 p||.2(S M S \times 2), 22 q| \mid .2(\text { TUPLE } \mid X 2)\end{array}$ & \\
\hline
\end{tabular}

$M=$ male,$F=$ female,$N R M=$ normal,$A B N=$ abnormal, $\mathrm{DD}=$ development delay, $M R=$ mental retardation, $\mathrm{FTT}=$ failure to thrive.

age was 4 years. Sex ratio was 4.5 males to 1 female [354:79] (Table 1). A chromosome abnormality was found in 14/421 [3.33\%] cases. A Fragile-Xq27.3 was diagnosed in $7 / 316$ [2.2\%].

Chromosome abnormalities are summarized in Table 2: The aberrations were: $4 / 14$ [28\%] supernumerary markers from cs 15 [3] and cs 2 [1] (Fig 1a); 4/14 [28\%] deletions of $2 \mathrm{q} 37.3,3 \mathrm{p} 25,12 \mathrm{q} 21.2 \mathrm{q} 23.3$ and $13 \mathrm{q} 13.2 \mathrm{q} 14.1$ (Fig 1b); $1 / 14$ [7\%] duplication of $15 q 11.2 q 13 ; 3 / 14$ [21\%] inversions of 10p11.2q21.2, 17q23q25 (de novo) and 14q11.2q33 (mosaic) (Fig 1c); 2/14 [14\%] translocations, one balanced $\mathrm{t}(1 ; 14)$ and one unbalanced $\operatorname{der}(14 ; 18)$ (Fig $1 d)$.

The 3/4 marker/ring had a 15 centromere signal by FISH and had either nil, one or two signals for D15S11, that demarcates the involvement of the critical region of Prader Willi/Angelman syndrome (Table 2).

Fluorescence in situ hybridization was performed on 23 of 433 patients for reasons other than to characterize a cytogenetic abnormality, 3 to rule out Williams-Beuren Syndrome, 5 for DiGeorge syndrome, 7 for proximal duplication of D15S11, 6 for subtelomere rearrangements, 1-for subtelomere rearrangement \& proximal duplication D15S11 and 1 for duplication D15S11, Smith-Magenis Syndome, and DiGeorge Syndrome. All 23 FISH tests were negative (Table 3 ).

Fragile X (Table 4): The mutations detected were: A full mutation ( $\mathrm{fM}$ ) and abnormal methylation in 3 [43\%] and mosaic mutations with partial methylation of variable clinical significance in 3 [43\%]. The mosaic size mutations were: an fM [200-900 repeats(r)] / deletion mutation [30 r] with partial methylation. The faint bands for the full mutation and deletion mutation may be a reflection of the sample quality (Fig 2, Lane 5). Two size mosaics had permutation (pM) [150 r]/fM [400 r] (Fig 2), and pM [155 r]/fM [800 r] with normal and abnormal methylation. A premutation mosaic female carrier with an atypical EcoR1 and Eag1 pattern and a typical BssH1 pattern gave 2.8, 3.0, 5.2-5.4 Kb bands, the Eag1 pattern suggested a DNA sequence change [14\%]. PCR gave reproducible bands corresponding to 29, 65, 80 repeats and a faint band for 39 repeats. Intermediate mutation (45-54 r) was found in 5 males and 2 females. 


\section{Mosaic Fragile X mutations}

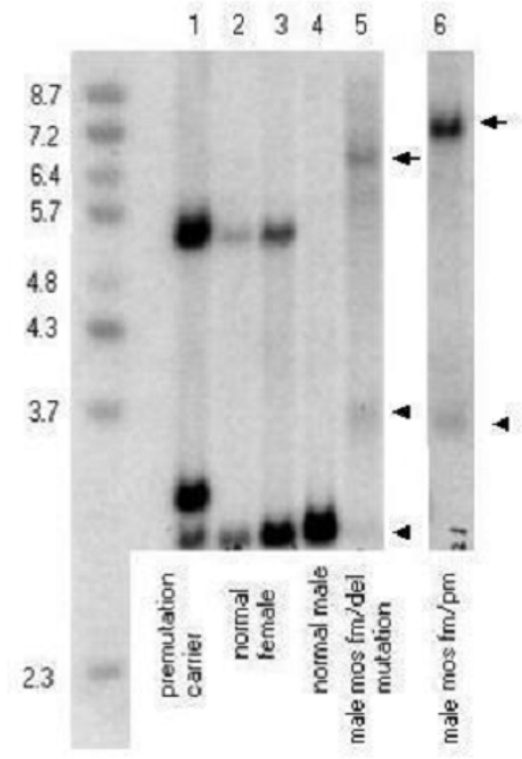

Figure 2

\section{Figure 2}

Mosaic fragile $X$ mutations: Southern blot using probe StBI2.3 on EcoRI and Eag I (methylation-sensitive enzyme) digested DNA. Lane I - permutation carrier, Lane 2 \& 3 normal female, Lane 4 - normal male, Lane 5 - an ASD male mosaic with fm (3.7 and 5.8-7.9 kb, 200-900 r)(arrows)/a deletion mutation (2.8 kb faint band, $30 \mathrm{r}$ )(arrow). By PCR a 30 repeats and $>200$ repeats were amplified. Lane $6-$ an ASD male mosaic fm (6.4 kb, $400 \mathrm{r}) / \mathrm{pm}(3.3 \mathrm{~kb}, 150 \mathrm{r})$.

\section{Discussion \\ Chromosomal causes of secondary Autism Spectrum Disorder (ASD)}

About $1.7 \%$ to $4.8 \%$ of individuals with ASD have chromosome abnormalities, including unbalanced translocations, inversions, rings, and interstitial deletions and duplications (Table 5). The chromosome abnormalities that have been reported on more than one occasion are duplication of $15 \mathrm{q}$, deletions of $18 \mathrm{q}, \mathrm{Xp}, 2 \mathrm{q}$ and the sex chromosome aneuploidies 47,XYY and 45,X [16].

A recent FISH subtelomere study found one out of ten unselected patients with ASD had a subtelomeric 2qter deletion [17]. In our experience 7/7 ASD patients were negative for subtelomeric rearrangements.
Children with Down syndrome have autism more commonly than expected. The incidence was at least $7 \%$ in one study [18]. This finding suggests that chromosome abnormalities may lower the threshold for the expression of autism.

In our study $(4 / 14=28 \%)$ and in other surveys, the common recurring chromosomal abnormality was duplication of the proximal $15 \mathrm{q}$ region (Table 5). About $1 \%$ of individuals with ASD have a chromosomal duplication in the Prader-Willi/Angelman region of proximal $15 \mathrm{q}$ $[[19,20]$, present study 4/421[0.95\%]]. The duplicated region $\mathrm{q} 11.2 \mathrm{q} 13$ is on the maternal chromosome 15 in autistic patients [21-23]. Most commonly, this is a supernumerary isodicentric $15 \mathrm{q}$ chromosome detectable by routine cytogenetic studies or, less commonly, an interstitial duplication of the region detected by FISH analysis for the SNRPN gene region. These two chromosome abnormalities have only subtle effects on the physical phenotype. Supernumerary isodicentric $15 \mathrm{q}$ chromosomes are de novo occurrences. Duplication of proximal $15 \mathrm{q}$ may result from segregation of a parental chromosome translocation or an interstitial $15 \mathrm{q}$ duplication. An abnormal gene dosage within 15q11.2-q13 might cause susceptibility to autism.

The 15q11-q13 region is shown schematically in Figures 3 \&4. Chromosome 15q11.2-q13 has gained support as an autism candidate region on the basis of the association of maternally derived chromosomal duplications of this region with an autistic phenotype [20,24-27] and genetic evidence for linkage and allelic association in the same interval in chromosomally normal autism families [2834]. The maternal specificity of chromosome 15 duplications in autism suggests a genomic imprinting effect. There are multiple imprinted genes in 15q11.2-q13, and two neurodevelopmental disorders exhibiting opposite patterns of genomic imprinting have been mapped to this region [35-37]. Interstitial deletion of 15q11.2-q13 specific for the paternal chromosome is the most frequent cause of Prader-Willi syndrome (PWS; MIM 176270), whereas maternal-specific deletion of the same common interval results in Angelman syndrome (AS; MIM 105830). The converse of Angelman Syndrome is observed in autism, that is a maternal duplication. The four causes of Angelman syndrome are 1) maternal deletion of 15q11.2q13, 2) paternal UPD15 3) mutations in UBE3A 4) mutations leading to imprinting errors of this region. A population-based study showed a high rate of ASD in AS [38]. But, a mutation was not identified in the UBE3A putative promoter or coding region in 10 idiopathic ASD patients [39]. Lack of expression of the maternally expressed UBE3A gene in the brain is thought to be the cause of AS. Since patients with deletions compared to other types of AS mutations have a more severe 


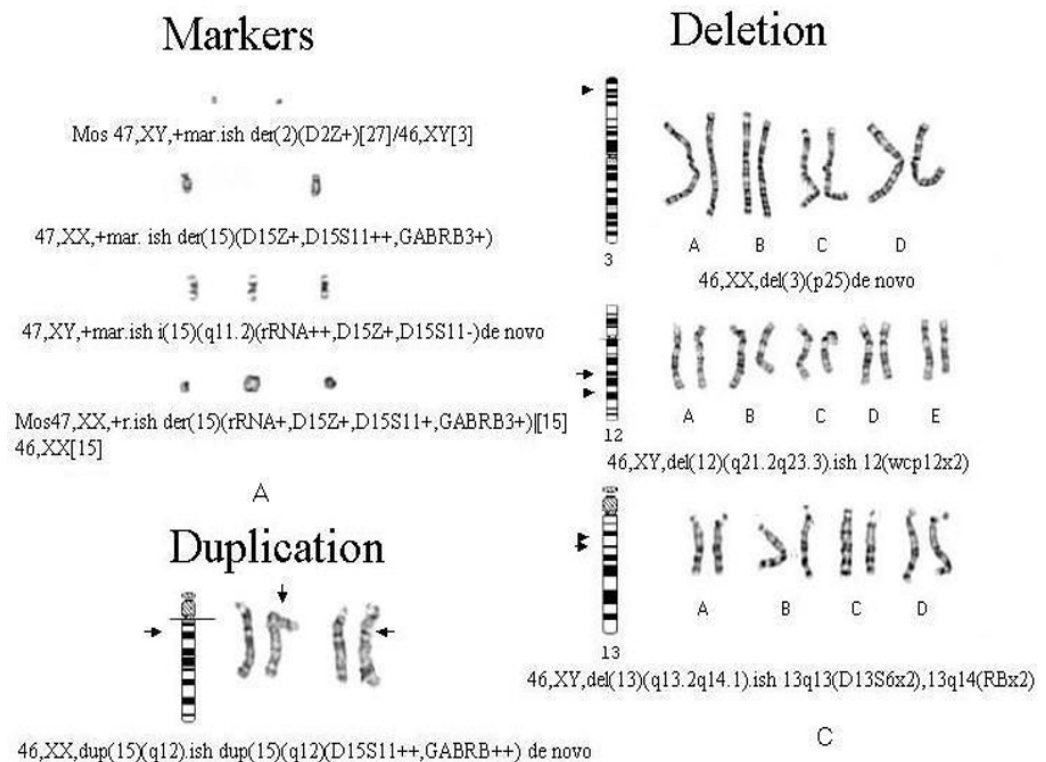

B
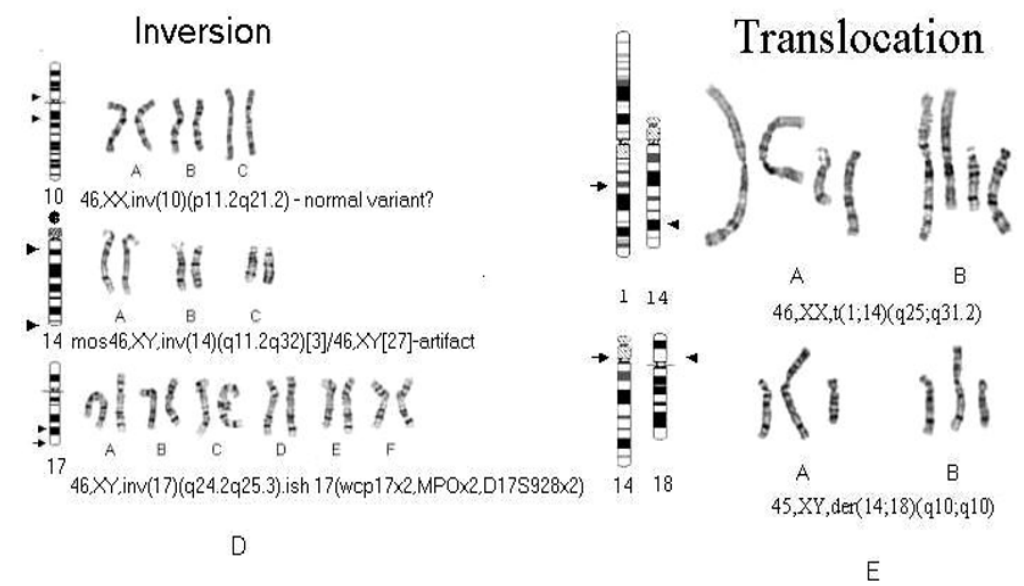

Figure 1

Figure I

Chromosome abnormalities in patients with autistic traits (A) 4 markers: [multiple copies] derived from chromosome 2 [I], I5 [3] with nomenclature (B) I duplication of chromosome I 5 with arrow denoting the region involved (C) 3 partial deletions (right homolog)(multiple copies) of 3p25, I2q21.2q23.3 \& I3ql3.2ql4.I with the ideogram, the arrows denote the deleted region. (D) 3 inversions (the right homolog) (multiple copies), inv(I0)(pI I.2q2I.2), inv( I4)(ql I.2q32), inv(I7)(q24.2q25.3) with arrows on the ideogram showing the inverted region (E) 2 translocations (partials in 2 copies, chromosomes involved (right) and their normal homolog (left)) one apparently balanced $t(I ; \mid 4)(q 25 ; q 3 \mid .2)$ and one unbalanced der(I4;|8)(qI0;ql0). The ideogram with arrows show the breakpoints 
Table 4: The details of Fragile $X$ mutations found in $2.2 \%(7 / 316)$ patients with a clinical indication of autism

\begin{tabular}{|c|c|c|c|c|c|c|c|}
\hline SI \# & $\begin{array}{l}\text { Age In } \\
\text { years }\end{array}$ & Sex & Clinical indication & FRAXA Result & Methylation & $\begin{array}{l}\text { Chrom } \\
\text { Result }\end{array}$ & $\begin{array}{l}\text { FISH } \\
\text { Result }\end{array}$ \\
\hline & & & & Full mutation $3 / 7=43 \%$ & & & \\
\hline I & 4.5 & M & Autism & ABN-Full mutation $(400,533,667$ repeats $[r])$ & abnormal methylation & $46, X Y$ & NT \\
\hline 2 & 5 & M & Autism & ABN-Full mutation $(600-1100 \mathrm{r})$ & abnormal methylation & $46, X Y$ & NT \\
\hline \multirow[t]{2}{*}{3} & 4.5 & M & Autism, DD & ABN- Full mutation (267-933 r), & abnormal methylation & $46, X Y$ & NT \\
\hline & & & & Mosaic mutation $3 / 7=43 \%$ & & & \\
\hline 4 & 2.3 & M & Autism & $\begin{array}{l}\text { ABN-size mosaic Full mutation }[800 \mathrm{r}] / \text { premutation } \\
{[155 \mathrm{r}]}\end{array}$ & $\begin{array}{l}\text { Normal \& abnormal } \\
\text { methylation }\end{array}$ & $46, X Y$ & NT \\
\hline 5 & 1.7 & M & Autism & $\begin{array}{l}\text { ABN-size mosaic Full mutation }[400 \mathrm{r}] / \text { premutation } \\
{[150 \mathrm{r}]}\end{array}$ & $\begin{array}{l}\text { Normal \& abnormal } \\
\text { methylation }\end{array}$ & $46, X Y$ & $\begin{array}{l}\text { Normal } \\
\text {-sub tel }\end{array}$ \\
\hline \multirow[t]{2}{*}{6} & 8.5 & M & Autism, DD & $\begin{array}{l}\text { ABN-mosaic Full mutation [200-900 r]/ deletion } \\
\text { mutation }[30 \mathrm{r}] \text {, }\end{array}$ & partial methylation & $46, X Y$ & NT \\
\hline & & & & Mosaic Premutation carrier I/7 = $14 \%$ & & & \\
\hline \multirow[t]{2}{*}{7} & 6 & $\mathrm{~F}$ & Autism & ABN- premutation mosaic $[29,65,80,39$ (light band)r $]$ & & $46, X X$ & NT \\
\hline & $\begin{array}{l}\text { Av } 4.36 \\
\text { years }\end{array}$ & $\begin{array}{l}2 F \\
5 M\end{array}$ & & Intermediate mutation 7 cases with $45-54 r$ & & & \\
\hline
\end{tabular}

$\mathrm{DD}=$ developmental delay, $\mathrm{NT}=$ not tested

phenotype, suggests the involvement of additional gene losses, such as GABAA receptor gene cluster [40]. Transcripts increased in patients with duplications 15q11.2q13 are maternal UBE3A [41], maternal ATP10C $[40,42]$ and other transcripts including antisense transcripts that could regulate gene expression [43] and may contribute to the duplication phenotype. Therefore, over expression of genes in 15q11-q13 probably confers ASD risk. Region proximal to D15S11 is considered to have no phenotypic effect. However, one of our patients had a marker 15 negative for D15S11, therefore, some duplications of 15, proximal to D15S11 and the autism candidate region may also influence susceptibility to autistic traits.

Initial studies to characterize the phenotype of $15 \mathrm{q} 11.2 \mathrm{q} 13$ duplication patients have found variation among affected people including mental retardation, motor coordination problems, seizure disorder, and impairments in attention, communication, and social function (some but not all with ASD or attention deficit hyperactivity disorder (ADHD)) [44,45]. It appears there may be a parent-of-origin effect on the linkage and association signals in this region of UBE3A and ATP10C $[46,32,33]$. Further studies across data sets, and rigorous evaluation of potential functional effects of associated alleles, and a thorough assessment of haplotype transmission within ATP10C and neighboring genes would be conclusive. The majority of linkage and association data point to the GABRB3 gene, which is one of a cluster of $\gamma$-aminobutyric acid (GABA) receptor subunits that map to the distal, apparently nonimprinted segment of the duplicated region (Fig. 3). Although a number of groups have detected genetic effects at GABRB3 in independent autism populations [29-31], other studies have failed to replicate these observations [47-49].

Yardin et al 2002 [50] recommended a systematic screening by FISH, of chromosome region 15q11.2q13 in cases with autistic-like syndrome

A deletion of $2 \mathrm{q} 37.3$ was identified by FISH in a patient with autism and macrocephaly in our study. Wolff et al 2002 [51] also reported an autistic patient with a 2q37.3 deletion detected using subtelomere probes. Whole genome screens have suggested several chromosomal regions that are potentially associated with a susceptibility gene for autism. [52-57]. Three studies revealed positive linkage to $2 q[52,53,57]$ and a third study demonstrated linkage to distal $2 \mathrm{q}$ in a subset of patients with autism and delayed onset of phrase speech [53]. Genomic scans are limited by the number of loci that are assessed; therefore, not all areas may be equally represented. It is important to note that telomeric regions may have increased meiotic recombination and may be under-represented in these types of analyses. Thus, the FISH approach is an important correlative study in the search for susceptibility genes. Macrocephaly in ASD: most children with autism are born with normal head circumference and about $20 \%$ meet the 
Table 5: Summary of reported population studies to assess the frequency of chromosome abnormalities (excluding fragile sites, polymorphisms and single cell abnormalities)

\begin{tabular}{|c|c|c|c|}
\hline Study & $\begin{array}{l}\text { Subjects } \\
\text { karyotyped }\end{array}$ & Chromosome abnormality & Clinical diagnosis \\
\hline \multirow[t]{7}{*}{$\begin{array}{l}\text { Konstantareas \& Homatidis } 1999 \\
{[123]}\end{array}$} & 127 & 6 [4.7\%] & $\begin{array}{l}\text { Diagnosed using the clinical criteria of autistic } \\
\text { disorder by DSM-III (1983-1989) }\end{array}$ \\
\hline & & $46, X Y, \operatorname{inv}(2)(p|| q \mid 3) p a t, 3 q^{+}$ & \\
\hline & & $47, X Y,+\operatorname{mar}$ & \\
\hline & & $47, X Y,+$ mar & \\
\hline & & $47, X X,+13$ & \\
\hline & & $\begin{array}{l}47, X X,+ \text { inv } \operatorname{dup}(15)(\text { pter } \rightarrow q|3:: q| 3 \rightarrow \\
\text { pter) }\end{array}$ & \\
\hline & & $\begin{array}{l}47, X Y,+\operatorname{der}(I 5)(\text { pter } \rightarrow \text { q } \mid 5:: \text { pl I } \rightarrow \\
\text { pter)de novo }\end{array}$ & \\
\hline \multirow[t]{3}{*}{$\begin{array}{l}\text { Gillberg \& Wahlstrom } 1985 \\
\text { [124] }\end{array}$} & 46 & $2[4.3 \%]$ & $\begin{array}{l}\text { Diagnosed using the American Psychiatric } \\
\text { Association (1980) criteria DSM-III }\end{array}$ \\
\hline & & $47, X Y,+21$ & \\
\hline & & $47, X Y Y$ & \\
\hline \multirow[t]{5}{*}{ Lauritsen 1999 [122] } & 145 & $4[2.8 \%]$ & $\begin{array}{l}\text { Cases with psychotic symptoms before } 2-3 \text { years or } \\
\text { beginning at 2-3 or later between 1969-1993 }\end{array}$ \\
\hline & & $47, X X,+m a r, ? t(13 ; 22)$ & \\
\hline & & $46, X X, t(9 ; 10)(p 23 ; q 23.1)$ & \\
\hline & & $46, X Y, \operatorname{inv}(10)(\mathrm{pl} 1.21 ; q 21.2) \mathrm{mat}$ & \\
\hline & & $46, X Y, t(7 ; \mid 12)(q 21.4 ; q 15)$ de novo & \\
\hline \multirow[t]{6}{*}{$\mathrm{Li} 1993[121]$} & 104 & $5[4.8 \%]$ & $\begin{array}{l}\text { Diagnosed using the American Psychiatric } \\
\text { Association (1980 \& 1987) guidelines, DSM-III \& III-R }\end{array}$ \\
\hline & & $47, X Y,+21$ & \\
\hline & & $46, X Y / 47, X Y,+21[12 / 88]$ & \\
\hline & & $46, X Y, t(5 ; 6)(q \mid 3 ; p 23)$ de novo & \\
\hline & & $46, X, \operatorname{inv}(Y)(p I I q I I)$ & \\
\hline & & 46,fra $(X)(q 27.3), \operatorname{inv}(Y)(p|| q \mid l)$ & \\
\hline \multirow[t]{2}{*}{ Weidmer-Mikhail 1998 [120] } & 59 & $\mathrm{I}[\mathrm{l} .69 \%]$ & DSM-III-R (|99|-1995) \\
\hline & & Tetrasomy 15 & \\
\hline \multirow[t]{5}{*}{ Ritvo 1990 [6] } & 233 & 9 [3.9\%] & DSM-III (1984-1988) \\
\hline & & 6-trisomy 21 & \\
\hline & & Partial trisomy 8 & \\
\hline & & Deletion 9p & \\
\hline & & $46, X X, t(5 q ; I I q) p a t$ & \\
\hline \multirow[t]{11}{*}{ Wassink 200I [119] } & 278 & $13[4.7 \%]$ & DSM-III,-III-R \& -IV (I980-1999) \\
\hline & & $46, X X, \operatorname{del}(8)(\mathrm{p} 23)$ & $\begin{array}{l}\text { MR, diaphragmatic hernia, hemivertebra, 2-vessel } \\
\text { umbilicus, strabismus }\end{array}$ \\
\hline & & $47, \mathrm{XX}, \operatorname{der}(14) \mathrm{t}(14 ; ?)(\mathrm{q} 22 ; ?)$ & MR, abnormal facies \& palate, failure to thrive \\
\hline & & $46, X X, \operatorname{dup}(\mid 5)(q|| .2 ; q \mid 3)$ & MR, abnormal EEG, precocious puberty \\
\hline & & $2-46, X Y, \operatorname{del}(\mid 5)(q|| .2 q \mid 3)$ & Mild MR Moderate MR \& Seizures \\
\hline & & mat47,XX,+mar de novo $47, X X,+$ mar & $\begin{array}{l}\text { McCune-Albright syndrome Microcephaly, abnormal } \\
\text { facies }\end{array}$ \\
\hline & & $47, X Y,+\operatorname{del}(15)(q 22)$ & $M R$ \\
\hline & & $46, X Y, \operatorname{del}(16)(q 13 q 22)$ & $\begin{array}{l}\text { MR, Seizures, failure to thrive, abnormal facies, } \\
\text { webbed neck macrocephaly, syndactyly }\end{array}$ \\
\hline & & $46, X Y, a d d(17)(q 23)$ & MR \& abnormal facies \\
\hline & & $2-47, X X,+21$ & $\begin{array}{l}\text { MR, heart murmur, esotropia, recurrent pneumonia. } \\
\text { MRIVSD, pneumonia and seizures }\end{array}$ \\
\hline & & $46, X Y, \operatorname{add}(22)(q \mid 3)$ & Macrocephaly and failure to thrive \\
\hline Present & 421 & 14 [3.3\%] & $\begin{array}{l}\text { Physician referrals to a genetic lab. 1995-2003 } \\
\text { March }\end{array}$ \\
\hline
\end{tabular}




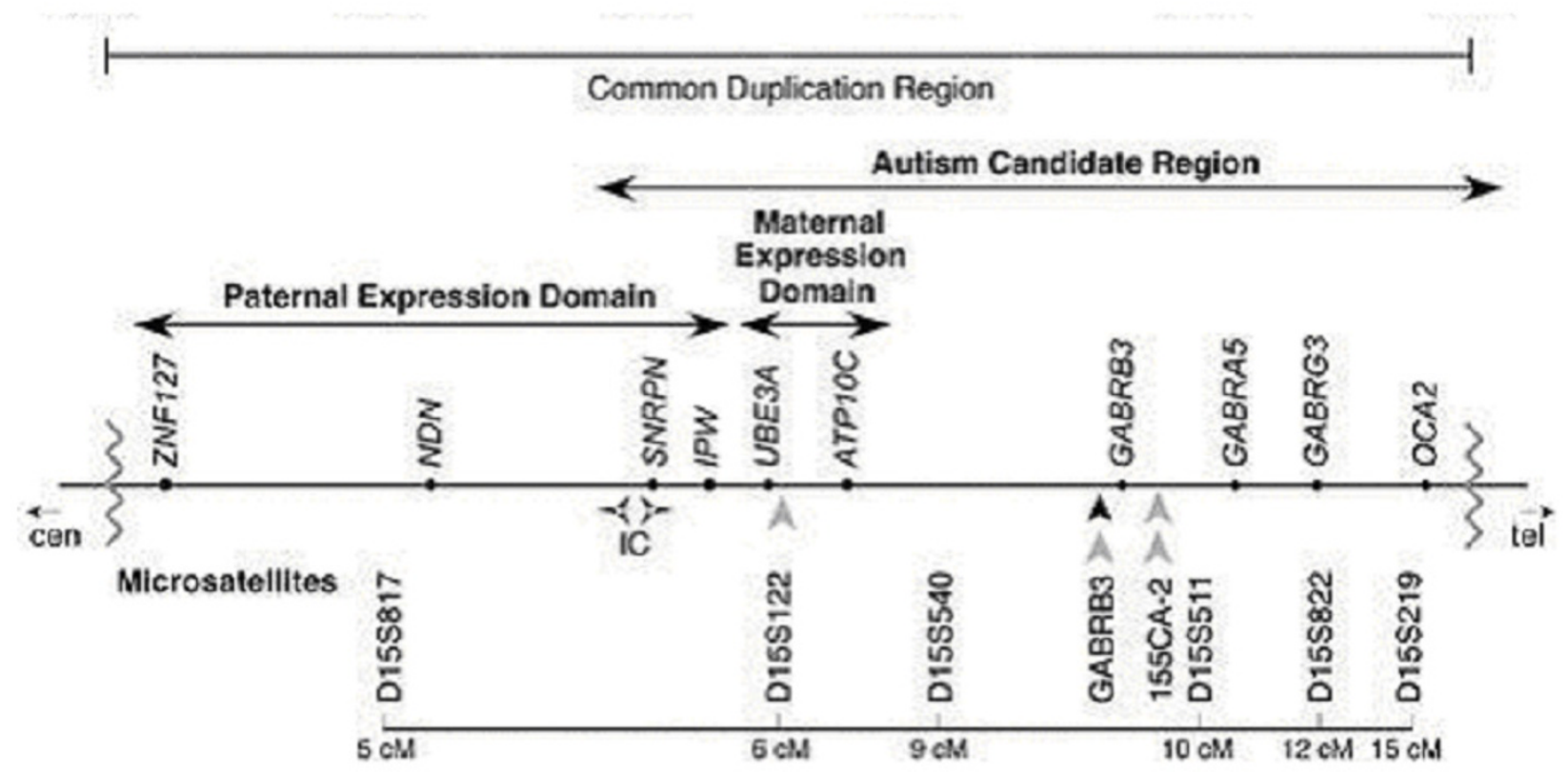

Figure 3

\section{Figure 3}

Chromosome I5qII-qI 3 region showing the autism candidate region. A schematic representation of the I5qII-q 3 interval duplicated in autism cases and deleted in Prader-Willi/Angelman syndrome is shown. IC denotes the position of the I5q imprinting center. Loci corresponding to previous reports of linkage and association are indicated by dark and light arrowheads, respectively, below the map. (Adapted with permission from Sutcliffe J et al article "Dense linkage disequilibrium mapping in the $15 \mathrm{ql} / \mathrm{-q} / 3$ maternal expression domain yields evidence for association in autism' in Molecular Psychiatry (2003) 8, 624-634)

criteria for macrocephaly [58]. The increased rate of growth in head circumference appears to be most dramatic in the first year of life and corresponds to increased growth of the cerebral cortex as measured by MRI [59].

A de novo deletion of chromosome 3, del(3)(p25), was found in one case with ASD and development delay in our patient pool. A deletion of $3 \mathrm{q}$ region was found by Konstantareas \& Homatidis 1999 [60]. Genome wide scan found a major susceptibility locus at 3q25-27 and there was also allelic association in families with autism spectrum disorder originating from a subisolate of Finland $[61,62]$. Animal models and linkage data from genome screens implicate the oxytocin receptor at 3p25-p26 $[61,62]$.

To date, there have been no reports of $12 \mathrm{q}$ deletions in patients with ASD, to the best of our knowledge. For the first time we report an interstitial deletion 46,XY,del(12)(q21.2q23.3) in a patient with ASD, development delay, mental retardation, multiple congenital abnormality, and family history of Down syndrome.

46,XY,del(13)(q13.2q14.1)de novo was found in one of our patients' with ASD. Hyperserotonemia in autism is one of the longest-standing biochemical findings. The 


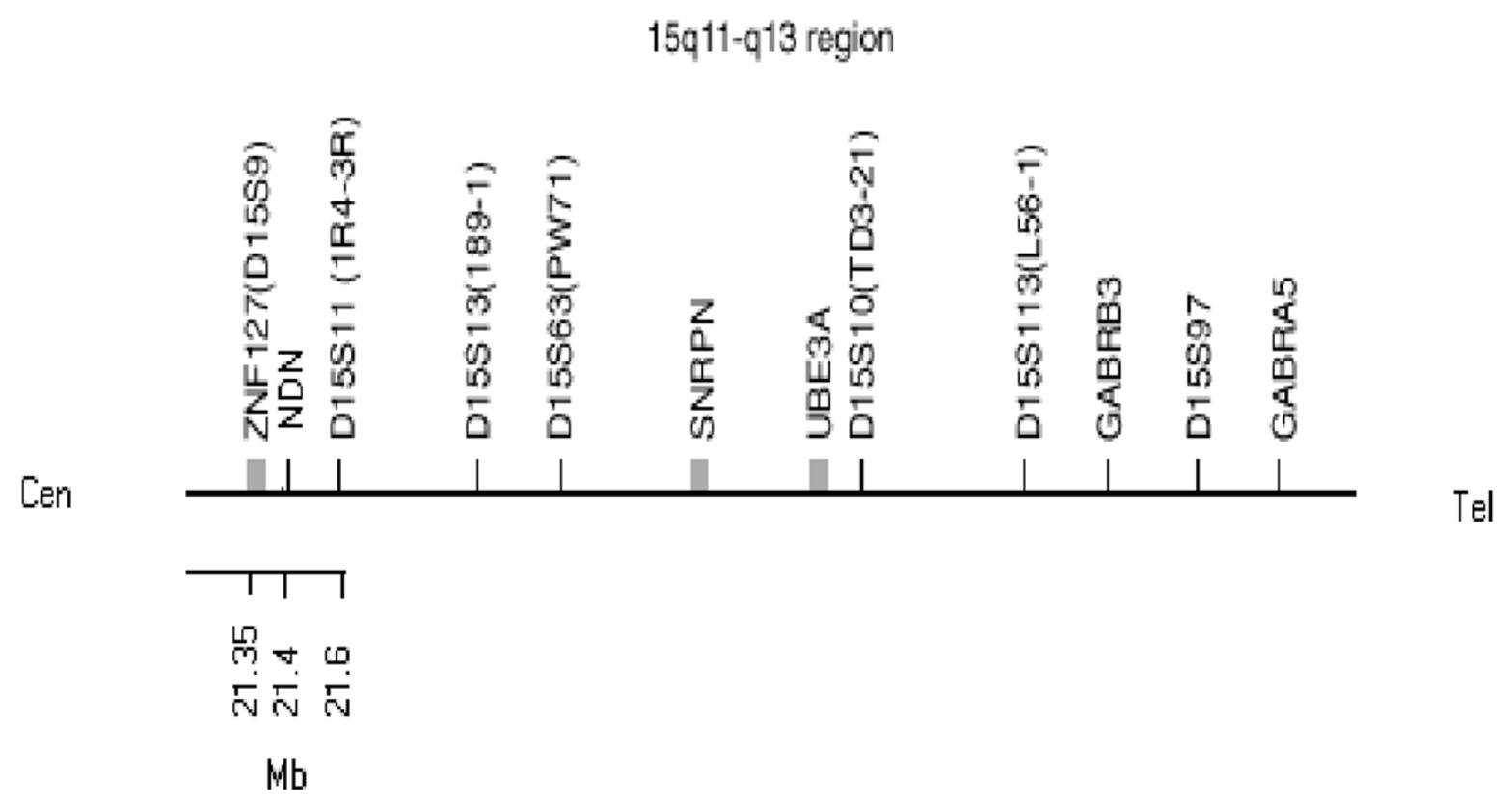

Figure 4

Figure 4

The map location of DI5SI I probe used to characterize the markers

serotonin 2A receptor gene (HTR2A) on chromosome $13 q 14 q 21$ is a primary candidate gene in autism. Converging data from recent genome screens also implicates the genomic region containing HTR2A [63-66]. Correlation of HTR2A disruption or deletion in our case with a 13q13.2q14.1 deletion and other 13q deletion in ASD patients would complement genome screen data.

The recent physical mapping of the serotonin 5-HT(7) receptor gene (HTR7) to 10q23 [67] raises the question if the inversion inv(10)(p11.2q21.2) present in our patient, which is considered a normal familial variant could have long range influence on HTR7 and susceptibility to autism in some cases.
So far there has been no observed association or link between chromosome 14 and ASD. Also, the mosaic inversion $\operatorname{inv}(14)(q 11.2 q 33)$ [3/20] found in one of our patients is considered a cultural artifact when seen in 1 or 2 cells.

In this study, a patient with inv(17)(q23q25)de novo, had ASD, hypotonia and developmental delay. Chromosome $17 \mathrm{q}$ shows association with autism by genome wide scans and in linkage studies $[57,66,68]$. There is also interest in $17 \mathrm{q}$ since serotonin transporter gene (SERT) has been mapped to17q11-q12 [69].

We report a patient with $18 \mathrm{p}$ deletion due to an unbalanced translocation between 14 and 18. Majority of the reported cases with autism involve deletion of $18 \mathrm{q}$ [70- 
72]. A deletion of the 18p-arm (at band 11.3) in about $50 \%$ cells and $50 \%$ of the cells with a duplication of the long arm in peripheral blood was described in a mildly obese girl with DSM-III-R autistic disorder and moderate mental retardation [73]. Another preschool girl with selective autism and a deletion of Chromosome 18p11.1 has also been described [74]. She had communication problems consistent with a diagnosis of autism. However, in the area of reciprocal social interaction she was a little less deviant than most children and had no major behavior problems typical of autistic disorder. Linkage and association studies have suggested at least 2 candidate loci, one on the short and the other on the long arms of chromosome 18 [75].

One of the breakpoints in the balanced translocation, $46, \mathrm{XX}, \mathrm{t}(1 ; 14)(\mathrm{q} 25 ; \mathrm{q} 31.2)$ was $1 \mathrm{q} 25$, in the present study. A recent report, links D1S1675 that maps to chromosome 1q24 with autism [76] using obsessive-compulsive behaviors as a restricting criterion for the analysis. The proximity of our breakpoint and D1S1675 may be coincidental or causal.

Although no cases with X-rearrangements were identified, in this study, the literature on abnormal X chromosome and autism is discussed as it has been cited in multiple cases. An autistic (ICD-10) woman had a translocation, $\mathrm{t}(\mathrm{X} ; 8)(\mathrm{p} 22.13 ; \mathrm{q} 22.1)$ [77], a boy with "autistic disorder" had duplication of Xp22 [78], and a de novo Xp22.3 deletion was observed in 3 autistic females [79]. Further, mutations in cell adhesion genes NLGN4 on Xp22.3 and NLGN3 on Xq13 are reported in patients with autism [80]. Therefore, subtle Xp rearrangements have to be considered in the cytogenetic assessment of ASD patients

\section{Fragile $X$ syndrome}

The typical clinical picture in FRAXA includes mental retardation, macro-orchidism, large ears, and prominent jaw. Within neurons, the FMR protein (FMRP) interacts with mRNA and ribosomes, suggesting a role in regulating protein synthesis [81]. FMRP is heavily synthesized in dendritic spines in response to synaptic activity, and abnormal dendritic spine size and shape have been noted in FRAXA patients and fmr1 knockout mice [82]. These abnormalities may correspond to an abnormal postsynaptic response that weakens synaptic connections [83].

A multicenter study in Sweden [84] found fragile $\mathrm{X}$ in 13 of 83 boys (16\%) with infantile autism but in none of 19 girls with infantile autism. Klauck et al. (1997) [85] concluded from molecular genetic studies of 141 patients from 105 simplex and 18 multiplex families that an association of autism with fragile $\mathrm{X}$ is nonexistent and that the Xq27.3 region is not a candidate for autism. Stoll (2001) [86] presented 11 children under the age of 8 years and the difficulties in diagnosis of fragile $\mathrm{X}$ syndrome at this age. The author concluded on the importance of fragile $\mathrm{X}$ DNA test for all children with mental retardation, autism, or significant developmental delay without a clear etiology. Whereas only a few percent of children with autism have fragile $\mathrm{X}$ syndrome, at least half of children with fragile $\mathrm{X}$ syndrome have autistic behaviors, including avoidance of eye contact, language delays, repetitive behaviors, sleep disturbances, tantrums, self-injurious behaviors, hyperactivity, impulsiveness, inattention, and sound sensitivities. The frequency of the fragile $\mathrm{X}$ syndrome among individuals with autism was ascertained up to 1993 using cytogenetic method. The incidence ranged from $12.7 \%-1.6 \%$. However, these studies had different criteria for classifying positive cases. The differences were: the number of metaphases analyzed ranged from 20 to 100 and the cut-off range from $1 \%$ to $4 \%$ metaphases with a fragile X [84,87-94]. Using molecular analysis the incidence of fragile X syndrome was 5\% (1/20) [95], 3.3\%(1/ 30) [96], 12\% (3/25) [97] and the present study $2.2 \%(7 /$ 316). The difference in incidence between the present $(2.2 \%)$ and previous studies $(3.3 \%-12 \%)$ may be due to small sample size in the other studies or clinical criteria for selection of patients or both.

\section{Mosaicism for FRAX mutation:}

Forty-three percent of FRAX patients had a mosaic mutation in our study. The prevalence of males who carry a full mutation and a permutation is $15-20 \%$ [98-102] among the affected individuals. Nolin et al 1994 [103] analyzed a group of affected fragile X males by Southern blotting and found $41 \%(61 / 148)$ to be mosaic. This observation of $41 \%$ is significantly higher than previous reports $15-$ $20 \%$. The difference could be technical modifications, which permitted the identification of faint premutation bands in some patients. The higher percentage (43\%) of affected males with mosaicism in our study suggests that the occurrence of such individuals may be frequent in patients with ASD.

The degree of mental retardation seemed not to be influenced by the presence of premutation alleles in some of the cells and a full mutation in the rest of the cells [104]. While Merenstein et al 1996 [105] study suggests there may be some variation of clinical expression in fragile $\mathrm{X}$ males with a full mutation and permutation. It has been hypothesized that these mosaic cases should show higher levels of functioning than those who have only the inactive full mutation gene, but previous studies have provided negative or equivocal results. In one study, the cross-sectional development of communication, self-care, socialization, and motor skills was studied in 46 males with fragile $\mathrm{X}$ syndrome under age 20 years as a function of two variables: age and the presence or absence of mosaicism. The rate of adaptive skills development was 2-4 
times greater in mosaic cases versus full mutation cases. FMR1 protein (FMRP) levels was shown to correlate with IQ, even in mosaic males for $38 \%$ of the IQ variance $[106,107]$. There was also a trend for cases with autism to be more prevalent in the full-mutation group [108]. However, we found a high incidence ( $43 \%$ ) of mosaic FRAX mutation in autistic patients, which requires confirmation in other FRAX studies of large cohorts of ASD patients.

\section{Deletion mutation}

The molecular mechanism of the FRAX is based on the expansion of a CGG repeat in the 5' UTR of the FMR1 gene in the majority of fragile $\mathrm{X}$ patients. The instability of this CGG repeats containing region is not restricted to the CGG repeat itself but expands to the flanking region as well. de Graaff et al 1996 [109] described four unrelated fragile $\mathrm{X}$ patients mosaic for both a full mutation and a small deletion in the CGG repeat containing region. Sequence analysis of the regions surrounding the deletions showed that both the (CGG)n repeat and some flanking sequences were missing in all four patients. The 5 ' breakpoints of the deletions were found to be located between 75-53 bp proximal to the CGG repeat. This suggests the presence of a hot spots for deletions in the CGG repeat region of the FMR1 gene and emphasizes the instability of this region in the presence of an expanded CGG repeat [110-113]. All reported cases had fragile X phenotype (which may be an ascertainment bias), and the deletion was usually a faint band suggesting a recent mutation in a small population of cells. Our case had an unusual Southern band pattern, consistent with the presence of both a full mutation (3.7 and 5.8-7.9 kb; 200-900 r)and a deleted $(2.8 \mathrm{~kb} ; 30 \mathrm{r})$ mutation with partial methylation. Since immunohistochemical staining or Western blot analysis was not performed to assess the FMRP production it precludes clinical correlation.

A 6-year old mosaic permutation female carrier had $29,65,80,39$ repeats. The autism spectrum disorder in our patient may be due to diminished translational efficiency in FMRP production. Tassone et al (2000) [114] [have shown FMRP in $61 \%$ and $70 \%$ lymphocytes in two females 91/2 years and 33 years of age with 103/33, 180/ 30 repeats and IQ of 49 and 90, respectively. The first patient has physical, cognitive, and behavioral features of the fragile $\mathrm{X}$ phenotype but FMRP was in the normal range, while the second patient also had FMRP level in the normal range was treated for depression and has a history of ovarian cyst, premature menopause at 27 years, and a hysterectomy at 31 years. She also experienced social anxiety, panic attacks, mood swings, and mild obsessive compulsive behaviors. Johnston et al. (2001) [115] recently observed that emotional problems, including depression and interpersonal sensitivity, were more likely to occur in carrier females with $>100$ repeats. Austism spectrum dis- order has been observed mostly in males with permutations $[114,116,117]$. The mosaic permutation in our female patient was 80 repeats as the largest expansion which is still below 100 repeats found in the affected cases in literature. Clinical correlation in our permutation mosaic case is hindered by the lack of FMRP studies and even so, the tissue distribution of mosaicism and FMRP profile would be the necessary phenotype determinant.

The significance of intermediate alleles found in $7 / 316$ (Average age 4.36 years) of our patients requires further exploration on larger independent samples as they may raise the threshold for important developmental disabilities and/or physical features [116].

The limitations of our retrospective study were a lack of uniform clinical criterion for inclusion and limited behavioral diagnostic information for purposes of dissecting the phenotype. However, for autism diagnosis it may be reliable, as shown in a recent study [118] which examined the UK General Practitioner Research Database (GPRD) and found the diagnosis of autism among general practitioners in the UK had a high positive predictive value.

\section{Conclusions}

In our experience, the incidence of chromosome (3.33\%) and fragile-X (2.2\%) abnormalities totals to $5.53 \%$ in a population of patients with an indication of autism sent for genetic testing. Since, $28 \%$ percent of chromosome abnormalities detected in our study were subtle; a high resolution cytogenetic study for ASD patients with a scrutiny of $15 q 11.2 q 13,2 q 37$ and Xp23.3 region should be standard practice. The higher incidence of mosaic fragile$\mathrm{X}$ mutations with partial methylation in our ASD population vs incidence of mosaicism in reported populations with fragile X syndrome [50\% vs $15-40 \%]$, suggests that faint bands and variations in the Southern band pattern may occur rather frequently in fragile $\mathrm{X}$ positive autistic patients. The mosaic FRAXA mutation with normal and abnormal or partial methylation may also enhance the threshold for autism spectrum disorder. Careful analysis and high quality gels are required to rule out the type of mutation in patients with autistic traits. FRMP estimates in positive cases would be an extremely useful adjunct especially in mosaic cases. Future studies are necessary to corroborate the high incidence of mosaicism and their role in ASD.

\section{Competing interests}

The author(s) declare that they have no competing interests.

\section{Acknowledgements}

I thank Bernice Allitto, Deborah Anaya for their help and everyone who contributed to this database. 


\section{References}

I. Constantino JN, Todd RD: Autistic traits in the general population: a twin study. Arch Gen Psychiatry 2003, 60:524-530.

2. Veenstra-VanderWeele J, Cook EH: Molecular genetics of autism spectrum disorder. Mol Psychiatry 2004, 9:819-32. Review

3. Barton M, Volkmar F: How commonly are known medical conditions associated with autism? J Autism Dev Disord 1998 28:273-8.

4. Centers for Disease Control and Prevention: Prevalence of Autism in Brick Township, New Jersey, 1998. Atlanta, Ga: Centers for Disease Control and Prevention; Community Report 2000 [http:// www.cdc.gov/ncbddd/dd/rpttoc.htm]

5. Chakrabarti S, Fombonne E: Pervasive developmental disorders in preschool children. JAMA 200I, 285:3093-9.

6. Ritvo ER, Jorde LB, Mason-Brothers A, Freeman BJ, Pingree C, Jones MB, McMahon WM, Petersen PB, Jenson WR, Mo A: The UCLAUniversity of Utah epidemiologic survey of autism: recurrence risk estimates and genetic counseling. Am J Psychiatry 1989, | 46: I032-6.

7. Bolton P, Macdonald H, Pickles A, Rios P, Goode S, Crowson M, Bailey A, Rutter M: A case-control family history study of autism. J Child Psychol Psychiatry 1994, 35:877-900.

8. Tuchman R: Autism. Neurol Clin 2003, 2 I:915-32. Review

9. Jamain S, Betancur C, Giros B, Leboyer M, Bourgeron T: Genetics of autism: from genome scans to candidate genes. Med Sci (Paris) 2003, 19:1081-90. Review

10. Ozonoff S, Williams BJ, Gale S, Miller JN: Autism and autistic behavior in Joubert syndrome. J Child Neurol 1999, I4:636-4I.

II. Waage-Baudet H, Lauder JM, Dehart DB, Kluckman K, Hiller S, Tint GS, Sulik KK: Abnormal serotonergic development in a mouse model for the Smith-Lemli-Opitz syndrome: implications for autism. Int J Dev Neurosci 2003, 2 I:45 I-9.

12. Bailey A, Luthert P, Dean A, Harding B, Janota I, Montgomery M, Rutter M, Lantos P: A clinicopathological study of autism. Brain 1998, I 2 I:889-905.

13. Folstein SE, Rosen-Sheidley B: Genetics of autism: complex aetiology for a heterogeneous disorder. Nat Rev Genet 200I, 2:943-55. Review

14. Pickles A, Bolton P, Macdonald H, Bailey A, Le Couteur A, Sim CH, Rutter $M$ : Latent-class analysis of recurrence risks for complex phenotypes with selection and measurement error: a twin and family history study of autism. Am J Hum Genet 1995, 57:717-26.

15. Lord C, Volkmar F: Genetics of childhood disorders: XLII, autism, part $\mathrm{I}$ : diagnosis and assessment in autistic spectrum disorders. I Am Acad Child Adolesc Psychiatry 2002, 4 I : I I34- I I 36.

16. Gillberg C: Chromosomal disorders and autism. J Autism Dev Disord 1998, 28:4I5-25.

17. Wolff DJ, Clifton K, Karr C, Charles J: Pilot assessment of the subtelomeric regions of children with autism: detection of a 2q deletion. Genet Med 2002, 4:10-4.

18. Kent L, Evans J, Paul M, Sharp M: Comorbidity of autistic spectrum disorders in children with Down syndrome. Dev Med Child Neurol 1999, 41:153-8.

19. Boyar FZ, Whitney MM, Lossie AC, Gray BA, Keller KL, Stalker HJ, Zori RT, Geffken G, Mutch J, Edge PJ, Voeller KS, Williams CA, Driscoll DJ: A family with a grand-maternally derived interstitial duplication of proximal I5q. Clin Genet 200I, 60:42I-30.

20. Wolpert CM, Menold MM, Bass MP, Qumsiyeh MB, Donnelly SL, Ravan SA, Vance JM, Gilbert JR, Abramson RK, Wright $\mathrm{HH}$, Cuccaro $M L$, Pericak-Vance MA: Three probands with autistic disorder and isodicentric chromosome I5. Am J Med Genet 2000, 96:365-72. Review

21. Repetto GM, White LM, Bader PJ, Johnson D, Knoll JH: Interstitial duplications of chromosome region $15 \mathrm{q} I \mathrm{IqI}$ 3: clinical and molecular characterization. Am J Med Genet 1998, 79:82-9.

22. Schroer RJ, Phelan MC, Michaelis RC, Crawford EC, Skinner SA, Cuccaro M, Simensen RJ, Bishop J, Skinner C, Fender D, Stevenson RE: Autism and maternally derived aberrations of chromosome I 5q. Am J Med Genet 1998, 76:327-36.

23. Gurrieri F, Battaglia A, Torrisi L, Tancredi R, Cavallaro C, Sangiorgi E, Neri G: Pervasive developmental disorder and epilepsy due to maternally derived duplication of I5qII-qI3. Neurology 1999, 52: I694-7.

24. Borgatti R, Piccinelli P, Passoni D, Dalpra L, Miozzo M, Micheli R, Gagliardi C, Balottin U: Relationship between clinical and genetic features in "inverted duplicated chromosome I5" patients. Pediatr Neurol 200 I, 24: I I I-6.

25. Browne CE, Dennis NR, Maher E, Long FL, Nicholson JC, Sillibourne J, Barber JC: Inherited interstitial duplications of proximal I5q: genotype-phenotype correlations. Am J Hum Genet 1997, 61:1342-52.

26. Cook EH Jr, Lindgren V, Leventhal BL, Courchesne R, Lincoln A, Shulman C, Lord C, Courchesne E: Autism or atypical autism in maternally but not paternally derived proximal $\mathbf{1 5 q}$ duplication. Am J Hum Genet 1997, 60:928-34

27. Robinson WP, Binkert F, Gine R, Vazquez C, Muller W, Rosenkranz $W$, Schinzel A: Clinical and molecular analysis of five inv dup( I 5) patients. Eur J Hum Genet 1993, I:37-50.

28. Bass MP, Menold MM, Wolpert CM, Donnelly SL, Ravan SA, Hauser ER, Maddox LO, Vance JM, Abramson RK, Wright HH, Gilbert JR, Cuccaro ML, DeLong GR, Pericak-Vance MA: Genetic studies in autistic disorder and chromosome I5. Neurogenetics 2000, 2:219-26.

29. Buxbaum JD, Silverman JM, Smith CJ, Greenberg DA, Kilifarski M, Reichert J, Cook EH Jr, Fang Y, Song CY, Vitale R: Association between a GABRB3 polymorphism and autism. Mol Psychiatry 2002, 7:3 II-6.

30. Cook EH Jr, Courchesne RY, Cox NJ, Lord C, Gonen D, Guter SJ, Lincoln A, Nix K, Haas R, Leventhal BL, Courchesne E: Linkage-disequilibrium mapping of autistic disorder, with I5qII-I3 markers. Am J Hum Genet 1998, 62:1077-83.

31. Martin ER, Menold MM, Wolpert CM, Bass MP, Donnelly SL, Ravan SA, Zimmerman A, Gilbert JR, Vance JM, Maddox LO, Wright HH, Abramson RK, DeLong GR, Cuccaro ML, Pericak-Vance MA: Analysis of linkage disequilibrium in gamma-aminobutyric acid receptor subunit genes in autistic disorder. Am J Med Genet 2000, 96:43-8.

32. Nurmi EL, Amin T, Olson LM, Jacobs MM, McCauley JL, Lam AY, Organ EL, Folstein SE, Haines JL, Sutcliffe JS: Dense linkage disequilibrium mapping in the $15 q|l-q| 3$ maternal expression domain yields evidence for association in autism. Mol Psychiatry 2003, 8:624-34. 570

33. Nurmi EL, Dowd M, Tadevosyan-Leyfer O, Haines JL, Folstein SE, Sutcliffe JS: Exploratory subsetting of autism families based on savant skills improves evidence of genetic linkage to I $5 q$ I I q I3. J Am Acad Child Adolesc Psychiatry 2003, 42:856-63.

34. Shao Y, Cuccaro ML, Hauser ER, Raiford KL, Menold MM, Wolpert CM, Ravan SA, Elston L, Decena K, Donnelly SL, Abramson RK, Wright HH, DeLong GR, Gilbert JR, Pericak-Vance MA: Fine mapping of autistic disorder to chromosome I $5 \mathrm{q}|\mathrm{I}-\mathrm{q}| \mathbf{3}$ by use of phenotypic subtypes. Am J Hum Genet 2003, 72:539-48.

35. Cassidy SB, Dykens E, Williams CA: Prader-Willi and Angelman syndromes: sister imprinted disorders. Am J Med Genet 2000 , 97:136-46. Review

36. Jiang Y, Tsai TF, Bressler J, Beaudet AL: Imprinting in Angelman and Prader-Willi syndromes. Curr Opin Genet Dev 1998, 8:334-42. Review

37. Nicholls RD: Genomic imprinting and uniparental disomy in Angelman and Prader-Willi syndromes: a review. Am J Med Genet 1993, 46: 16-25. Review

38. Steffenburg S, Gillberg CL, Steffenburg U, Kyllerman M: Autism in Angelman syndrome: a population-based study. Pediatr Neurol 1996, 14:131-136.

39. Veenstra-VanderWeele J, Gonen D, Leventhal BL, Cook EH Jr: Mutation screening of the UBE3A/E6-AP gene in autistic disorder. Mol Psychiatry 1999, 4:64-7.

40. Herzing LB, Kim SJ, Cook EH Jr, Ledbetter DH: The human aminophospholipid-transporting ATPase gene ATPIOC maps adjacent to UBE3A and exhibits similar imprinted expression. Am J Hum Genet 200 I, 68: I50I-I505.

4I. Herzing LB, Cook EH Jr, Ledbetter DH: Allele-specific expression analysis by RNA-FISH demonstrates preferential maternal expression of UBE3A and imprint maintenance within I 5q I I-q I 3 duplications. Hum Mol Genet 2002, I I: I707- I 7 I8.

42. Meguro M, Kashiwagi A, Mitsuya K, Nakao M, Kondo I, Saitoh S, Oshimura M: A novel maternally expressed gene, ATPIOC, encodes a putative aminophospholipid translocase associated with Angelman syndrome. Nat Genet 200I, 28:19-20.

43. Runte M, Huttenhofer A, Gross S, Kiefmann M, Horsthemke B, Buiting K: The IC-SNURF-SNRPN transcript serves as a host for 
multiple small nucleolar RNA species and as an antisense RNA for UBE3A. Hum Mol Genet 200I, 10:2687-2700.

44. Bolton PF, Dennis NR, Browne CE, Thomas NS, Veltman MW, Thompson RJ, Jacobs P: The phenotypic manifestations of interstitial duplications of proximal I $5 q$ with special reference to the autistic spectrum disorders. Am J Med Genet 200I, 1 05:675-85. Review

45. Thomas JA, Johnson J, Peterson Kraai TL, Wilson R, Tartaglia N, LeRoux J, Beischel L, McGavran L, Hagerman RJ: Genetic and clinical characterization of patients with an interstitial duplication I5q I I-q I 3, emphasizing behavioral phenotype and response to treatment. Am J Med Genet 2003, I I 9A(2): I | I-20.

46. Kim SJ, Herzing LB, Veenstra-VanderWeele J, Lord C, Courchesne R, Leventhal BL, Ledbetter DH, Courchesne E, Cook EH Jr: Mutation screening and transmission disequilibrium study of ATP I OC in autism. Am J Med Genet 2002, I / 4: I37-43.

47. Maestrini E, Lai C, Marlow A, Matthews N, Wallace S, Bailey A, Cook EH, Weeks DE, Monaco AP: Serotonin transporter (5-HTT) and gamma-aminobutyric acid receptor subunit beta3 (GABRB3) gene polymorphisms are not associated with autism in the IMGSA families. The International Molecular Genetic Study of Autism Consortium. Am J Med Genet 1999 88:492-6.

48. Nurmi EL, Bradford Y, Chen Y, Hall J, Arnone B, Gardiner MB, Hutcheson HB, Gilbert JR, Pericak-Vance MA, Copeland-Yates SA, Michaelis RC, Wassink TH, Santangelo SL, Sheffield VC, Piven J, Folstein SE, Haines JL, Sutcliffe JS: Linkage disequilibrium at the Angelman syndrome gene UBE3A in autism families. Genomics 200I, 77:105-13

49. Salmon B, Hallmayer J, Rogers T, Kalaydjieva L, Petersen PB, Nicholas $P$, Pingree C, McMahon W, Spiker D, Lotspeich L, Kraemer $H$ McCague P, Dimiceli S, Nouri N, Pitts T, Yang J, Hinds D, Myers RM, Risch $N$ : Absence of linkage and linkage disequilibrium to chromosome 15qII-q13 markers in 139 multiplex families with autism. Am J Med Genet 1999, 88:55I-6.

50. Yardin C, Esclaire F, Laroche C, Terro F, Barthe D, Bonnefont JP, Gilbert B: Should the chromosome region $|5 q| l|q| 3$ be tested systematically by FISH in the case of an autistic-like syndrome? Clin Genet 2002, 6 I:310-3.

51. Wolff DJ, Clifton K, Karr C, Charles J: Pilot assessment of the subtelomeric regions of children with autism: detection of a 2q deletion. Genet Med 2002, 4: 10-4.

52. Philippe A, Martinez M, Guilloud-Bataille M, Gillberg C, Rastam M, Sponheim E, Coleman M, Zappella M, Aschauer H, van Malldergerme L: Genome-wide scan for autism susceptibility genes. Paris Autism Research International Sibpair Study. Hum Mol Genet 1999, 8:805-8I2

53. Barrett S, Beck JC, Bernier R, Bisson E, Braun TA, Casavant TL, Childress D, Folstein SE, Garcia M, Gardiner MB, Gilman S, Haines JL, Hopkins K, Landa R, Meyer NH, Mullane JA, Nishimura DY, Palmer P, Piven J, Purdy J, Santangelo SL, Searby C, Sheffield V, Singleton J, Slager $\mathrm{S}$, et al.: An autosomal genomic screen for autism. Collaborative linkage study of autism. Am J Med Genet 1999, 88:609-I5.

54. Buxbaum JD, Silverman JM, Smith CJ, Kilifarski M, Reichert J, Hollander E, Lawlor BA, Fitzgerald M, Greenberg DA, Davis KL: Evidence for a susceptibility gene for autism on chromosome 2 and for genetic heterogeneity. Am J Hum Genet 200I, 68:1514-1520.

55. Risch N, Spiker D, Lotspeich L, Nouri N, Hinds D, Hallmayer Kalaydjieva L, McCague P, Dimiceli S, Pitts T, Nguyen L, Yang J, Harper C, Thorpe D, Vermeer S, Young H, Hebert J, Lin A, Ferguson J, Chiotti C, Wiese-Slater S, Rogers T, Salmon B, Nicholas P, Myers RM, et al: A genomic screen of autism: evidence for a multilocus etiology. Am J Hum Genet 1999, 65:493-507.

56. International Molecular Genetic Study of Autism Consortium: A full genome screen for autism with evidence for linkage to a region on chromosome 7q. Hum Mol Genet 1998, 7:57I-578.

57. International Molecular Genetic Study of Autism Consortium: A genomewide screen for autism: strong evidence for linkage to chromosomes 2q, 7q, and 16p. Am J Hum Genet 200I, 69:570-58।.

58. Fombonne E, Roge B, Claverie J, Courty S, Fremolle J: Microcephaly and macrocephaly in autism. I Autism Dev Disord 1999, 29:113-119.
59. Courchesne E, Carper R, Akshoomoff N: Evidence of brain overgrowth in the first year of life in autism. JAMA 2003, 290:337-344.

60. Konstantareas MM, Homatidis S: Chromosomal abnormalities in a series of children with autistic disorder. J Autism Dev Disord 1999, 29:275-85.

61. Auranen M, Vanhala R, Varilo T, Ayers K, Kempas E, Ylisaukko-Oja T, Sinsheimer JS, Peltonen L, Jarvela I: A genomewide screen for autism-spectrum disorders: evidence for a major susceptibility locus on chromosome 3q25-27. Am J Hum Genet 2002, $71: 777-90$.

62. Auranen M, Varilo T, Alen R, Vanhala R, Ayers K, Kempas E, Ylisaukko-Oja T, Peltonen L, Jarvela I: Evidence for allelic association on chromosome 3 q25-27 in families with autism spectrum disorders originating from a subisolate of Finland. Mol Psychiatry 2003, 8:879-84

63. Veenstra-VanderWeele J, Kim SJ, Lord C, Courchesne R, Akshoomoff $\mathrm{N}$, Leventhal BL, Courchesne E, Cook EH Jr: Transmission disequilibrium studies of the serotonin 5-HT2A receptor gene (HTR2A) in autism. Am J Med Genet 2002, I | 4:277-83.

64. Collaborative Linkage Study of Autism: Incorporating language phenotypes strengthens evidence of linkage to autism. Am J Med Genet 200I, 105:539-47.

65. Bradford Y, Haines J, Hutcheson H, Gardiner M, Braun T, Sheffield V, Cassavant T, Huang W, Wang K, Vieland V, Folstein S, Santangelo S, Piven J: Incorporating language phenotypes strengthens evidence of linkage to autism. Am J Med Genet 200I, 105:539-47.

66. Auranen M, Nieminen T, Majuri S, Vanhala R, Peltonen L, Jarvela I: Analysis of autism susceptibility gene loci on chromosomes I, 4 p, 6q, 7q, 13q, 15q, 16p, 17q, 19q and 22q in Finnish multiplex families. Mol Psychiatry 2000, 5:320-2.

67. Lassig JP, Vachirasomtoon K, Hartzell K, Leventhal M, Courchesne E, Courchesne R, Lord C, Leventhal BL, Cook EH Jr: Physical mapping of the serotonin 5-HT(7) receptor gene (HTR7) to chromosome 10 and pseudogene (HTR7P) to chromosome 12, and testing of linkage disequilibrium between HTR7 and autistic disorder. Am J Med Genet 1999, 88:472-5.

68. Yonan AL, Alarcon M, Cheng R, Magnusson PK, Spence SJ, Palmer AA, Grunn A, Juo SH, Terwilliger JD, Liu J, Cantor RM, Geschwind DH, Gilliam TC: A genomewide screen of $\mathbf{3 4 5}$ families for autismsusceptibility loci. Am J Hum Genet 2003, 73:886-97.

69. Murphy DL, Lerner A, Rudnick G, Lesch KP: Serotonin transporter: gene, genetic disorders, and pharmacogenetics. Mol Interv 2004, 4:109-23

70. Mahr RN, Moberg PJ, Overhauser J, Strathdee G, Kamholz J, Loevner LA, Campbell H, Zackai EH, Reber ME, Mozley DP, Brown L, Turetsky BI, Shapiro RM: Neuropsychiatry of I 8q-syndrome. Am J Med Genet 1996, 67:172-8.

7I. Seshadri K, Wallerstein R, Burack G: 18q-chromosomal abnormality in a phenotypically normal 2 i/2-year-old male with autism. Dev Med Child Neurol 1992, 34: 1005-9.

72. Wilson GN, Al Saadi AA: Obesity and abnormal behaviour associated with interstitial deletion of chromosome 18 (q I 2.2q2 I.I). J Med Genet 1989, 26:62-3.

73. Ghaziuddin M, Sheldon S, Tsai LY, Alessi N: Abnormalities of chromosome 18 in a girl with mental retardation and autistic disorder. J Intellect Disabil Res 1993, 37:3 I3-7.

74. Simons D, Goode S, Fombonne E: Elective mutism and chromosome 18 abnormality. European Child and Adolescent Psychiatry 1997, 6: II2-114.

75. Kamnasaran D: Genetic analysis of psychiatric disorders associated with human chromosome 18. Clin Invest Med 2003, 26:285-302

76. Buxbaum JD, Silverman J, Keddache M, Smith CJ, Hollander E, Ramoz $\mathrm{N}$, Reichert JG: Linkage analysis for autism in a subset families with obsessive-compulsive behaviors: evidence for an autism susceptibility gene on chromosome I and further support for susceptibility genes on chromosome 6 and 19. Mol Psychiatry 2004, 9: $144-50$

77. Bolton P, Powell J, Rutter M, Buckle V, Yates JRW, Ishikawa-Brush $Y$, Monaco AP: Autism, mental retardation, multiple exostoses and short stature in a female with $46, X, t(X ; 8)$ (p22.13;q22.1). Psychiatr Genet 1995, 5:5I-55.

78. Rao PN, Klinepeter K, Stewart W, Hayworth R, Grubs R, Pettenati M]: Molecular cytogenetic analysis of a duplication $X p$ in a 
male: further delineation of a possible sex influencing region on the X chromosome. Hum Genet 1994, 94: 149-I53.

79. Thomas NS, Sharp AJ, Browne CE, Skuse D, Hardie C, Dennis NR $\mathbf{X p}$ deletions associated with autism in three females. Hum Genet 1999, 104:43-8.

80. Jamain S, Quach H, Betancur C, Rastam M, Colineaux C, Gillberg IC, Soderstrom H, Giros B, Leboyer M, Gillberg C, Bourgeron T, Paris Autism Research International Sibpair Study: Mutations of the Xlinked genes encoding neuroligins NLGN3 and NLGN4 are associated with autism. Nature Genet 2003, 34:27-29.

81. Jin P, Warren ST: Understanding the molecular basis of fragile $X$ syndrome. Hum Mol Genet 2000, 9:90I-908.

82. Greenough WT, Klintsova AY, Irwin SA, Galvez R, Bates KE, Weiler IJ: Synaptic regulation of protein synthesis and the fragile $X$ protein. Proc Natl Acad Sci USA 200 I, 98:710I-7106.

83. Huber KM, Gallagher SM, Warren ST, Bear MF: Altered synaptic plasticity in a mouse model of fragile $X$ mental retardation. Proc Natl Acad Sci USA 2002, 99:7746-7750.

84. Blomquist HK, Bohman M, Edvinsson SO, Gillberg C, Gustavson KH, Holmgren $G$, Wahlstrom J: Frequency of the fragile $X$ syndrome in infantile autism. A Swedish multicenter study. Clin Genet 1985, 27: 1 13-7.

85. Klauck SM, Munstermann E, Bieber-Martig B, Ruhl D, Lisch S, Schmotzer G, Poustka A, Poustka F: Molecular genetic analysis of the FMR-I gene in a large collection of autistic patients. Hum Genet 1997, 100:224-9.

86. Stoll C: Problems in the diagnosis of fragile $\mathbf{X}$ syndrome in young children are still present. Am J Med Genet 200I, I 00: I I0-5.

87. Pueschel SM, Herman R, Groden G: Brief report: screening children with autism for fragile- $X$ syndrome and phenylketonuria. J Autism Dev Disord 1985, I 5:335-8.

88. Brown WT, Jenkins EC, Cohen IL, Fisch GS, Wolf-Schein EG, Gross A, Waterhouse L, Fein D, Mason-Brothers A, Ritvo E, et al.: Fragile $X$ and autism: a multicenter survey. Am J Med Genet 1986, 23:34I-52. Review

89. Wright HH, Young SR, Edwards JG, Abramson RK, Duncan J: Fragile $X$ syndrome in a population of autistic children. J Am Acad Child Psychiatry 1986, 25:64l-4.

90. Ho HH, Kalousek DK: Fragile $\mathbf{X}$ syndrome in autistic boys. Autism Dev Disord 1989, 19:343-7.

9I. Payton JB, Steele MW, Wenger SL, Minshew NJ: The fragile $\mathbf{X}$ marker and autism in perspective. J Am Acad Child Adolesc Psychiatry 1989, 28:417-2I.

92. Piven J, Gayle J, Landa R, Wzorek M, Folstein S: The prevalence of fragile $X$ in a sample of autistic individuals diagnosed using a standardized interview. J Am Acad Child Adolesc Psychiatry 1991, 30:825-30

93. Bailey A, Bolton P, Butler L, Le Couteur A, Murphy M, Scott S, Webb $T$, Rutter $M$ : Prevalence of the fragile $X$ anomaly amongst autistic twins and singletons. J Child Psychol Psychiatry 1993, 34:673-88.

94. Li SY, Chen YC, Lai TJ, Hsu CY, Wang YC: Molecular and cytogenetic analyses of autism in Taiwan. Hum Genet 1993, 92:44I-5.

95. Havlovicova M, Propper L, Novotna D, Musova Z, Hrdlicka M, Sedlacek Z: Genetic study of $\mathbf{2 0}$ patients with autism disorders. Cas Lek Cesk 2002, 141:38I-7. Czech

96. Estecio M, Fett-Conte AC, Varella-Garcia M, Fridman C, Silva AE: Molecular and cytogenetic analyses on Brazilian youths with pervasive developmental disorders. J Autism Dev Disord 2002 32:35-4I.

97. Gurling HM, Bolton PF, Vincent J, Melmer G, Rutter M: Molecular and cytogenetic investigations of the fragile $X$ region including the Frax A and Frax E CGG trinucleotide repeat sequences in families multiplex for autism and related phenotypes. Hum Hered 1997, 47:254-62.

98. Petek E, Kroisel PM, Schuster M, Zierler H, Wagner K: Mosaicism in a fragile $X$ male including a de novo deletion in the FMR I gene. Am J Med Genet 1999, 84:229-32.

99. Pieretti M, Zhang FP, Fu YH, Warren ST, Oostra BA, Caskey CT, Nelson DL: Absence of expression of the FMR-I gene in fragile $X$ syndrome. Cell 1991, 66:817-22

100. Rousseau F, Heitz D, Biancalana V, Blumenfeld S, Kretz C, Boue J, Tommerup N, Van Der Hagen C, DeLozier-Blanchet C, Croquette $M F$, et al:: Direct diagnosis by DNA analysis of the fragile $X$ syndrome of mental retardation. $N$ Engl J Med I99|, 325: $|673-8|$.
I0I. Rousseau F, Heitz D, Tarleton J, MacPherson J, Malmgren H, Dahl N, Barnicoat A, Mathew C, Mornet E, Tejada I, et al.: A multicenter study on genotype-phenotype correlations in the fragile $X$ syndrome, using direct diagnosis with probe StB 12.3: the first 2,253 cases. Am J Hum Genet 1994, 55:225-37.

102. van den Ouweland AM, de Vries BB, Bakker PL, Deelen WH, de Graaff E, van Hemel JO, Oostra BA, Niermeijer MF, Halley DJ: DNA diagnosis of the fragile $X$ syndrome in a series of 236 mentally retarded subjects and evidence for a reversal of mutation in the FMR-I gene. Am J Med Genet I994, 5 I:482-5.

103. Nolin SL, Glicksman A, Houck GE Jr, Brown WT, Dobkin CS: Mosaicism in fragile $\mathbf{X}$ affected males. Am J Med Genet 1994, 5I:509-I2.

104. de Vries BB, Wiegers AM, de Graaff E, Verkerk AJ, Van Hemel JO, Halley DJ, Fryns JP, Curfs LM, Niermeijer MF, Oostra BA: Mental status and fragile $X$ expression in relation to FMR-I gene mutation. Eur J Hum Genet 1993, I:72-9.

105. Merenstein SA, Sobesky WE, Taylor AK, Riddle JE, Tran HX, Hagerman RJ: Molecular-clinical correlations in males with an expanded FMR I mutation. Am I Med Genet 1996, 64:388-94.

106. Flora Tassone, Randi Hagerman J, David Iklé N, Pamela Dyer N, Megan Lampe, Rob Willemsen, Ben Oostra A, Annette Taylor: FMRP Expression as a Potential Prognostic Indicator in Fragile $\mathbf{X}$ Syndrome. American Journal of Medical Genetics 1999, 84:250-26I.

107. Loesch DZ, Huggins RM, Hagerman RJ: Phenotypic variation and FMRP levels in fragile X. Ment Retard Dev Disabil Res Rev 2004 10:3 I-4I. Review

108. Cohen IL, Nolin SL, Sudhalter V, Ding XH, Dobkin CS, Brown WT: Mosaicism for the FMRI gene influences adaptive skills development in fragile X-affected males. Am J Med Genet 1996, 64:365-9.

109. de Graaff E, de Vries BB, Willemsen R, van Hemel JO, Mohkamsing S, Oostra BA, van den Ouweland AM: The fragile $\mathbf{X}$ phenotype in a mosaic male with a deletion showing expression of the FMR I protein in 28\% of the cells. Am J Med Genet 1996, 64:302-8.

1 10. de Graaff E, Rouillard P, Willems PJ, Smits AP, Rousseau F, Oostra BA: Hotspot for deletions in the CGG repeat region of FMRI in fragile X patients. Hum Mol Genet 1995, 4:45-9.

III. Mila M, Castellvi-Bel S, Sanchez A, Lazaro C, Villa M, Estivill X: Mosaicism for the fragile $X$ syndrome full mutation and deletions within the CGG repeat of the FMRI gene. J Med Genet I996, 33:338-40.

I12. Mannermaa A, Pulkkinen L, Kajanoja E, Ryynanen M, Saarikoski S: Deletion in the FMRI gene in a fragile-X male. Am J Med Genet 1996, 64:293-5

II3. Schmucker B, Ballhausen WG, Pfeiffer RA: Mosaicism of a microdeletion of 486 bp involving the CGG repeat of the FMRI gene due to misalignment of GTT tandem repeats at chi-like elements flanking both breakpoints and a full mutation. Hum Genet 1996, 98:409-14.

1 14. Tassone F, Hagerman RJ, Taylor AK, Mills JB, Harris SW, Gane LW, Hagerman PJ: Clinical involvement and protein expression in individuals with the FMR I premutation. Am J Med Genet 2000, 91:144-52.

II5. Johnston C, Eliez S, Dyer-Friedman J, Hessl D, Glaser B, Blasey C, Taylor A, Reiss A: Neurobehavioral phenotype in carriers of the fragile X premutation. Am J Med Genet 200I, 103:3 I4-3I9.

116. Aziz M, Stathopulu E, Callias M, Taylor C, Turk J, Oostra B, Willemsen $\mathrm{R}$, Patton $\mathrm{M}$ : Clinical features of boys with fragile $\mathbf{X}$ premutations and intermediate alleles. Am J Med Genet 2003, I 2 | B: | | $9-27$

117. Hagerman PJ, Hagerman RJ: The fragile-X premutation: a maturing perspective. Am J Hum Genet 2004, 74:805-16. Review. Erratum in: Am J Hum Genet. 2004:75:352.

I 18. Fombonne E, Heavey L, Smeeth L, Rodrigues LC, Cook C, Smith PG, Meng $L$, Hall AJ: Validation of the diagnosis of autism in general practitioner records. BMC Public Health 2004, 4:5.

119. Wassink, Thomas H, Piven, Joseph, Patil, Shivanand R: Chromosomal abnormalities in a clinic sample of individuals with autistic disorder. Psychiatric Genetics 200I, I I:57-63.

120. Weidmer-Mikhail E, Sheldon S, Ghaziuddin M: Chromosomes in autism and related pervasive developmental disorders: a cytogenetic study. I Intellect Disabil Res I998, 42:8-12.

121. Li SY, Chen YC, Lai TJ, Hsu CY, Wang YC: Molecular and cytogenetic analyses of autism in Taiwan. Hum Genet 1993, 92:44I-445 
122. Lauritsen M, Mors O, Mortensen PB, Ewald H: Infantile autism and associated autosomal chromosome abnormalities: a register-based study and a literature survey. J Child Psychol Psychiatry 1999, 40:335-345.

123. Konstantareas MM, Homatidis S: Chromosomal abnormalities in a series of children with autistic disorder. J Autism Dev Disord 1999, 29:275-285.

124. Gillberg C, Wahlstrom J: Chromosome abnormalities in infantile autism and other childhood psychoses: a population study of 66 cases. Dev Med Child Neurol 1985, 27:293-304.

\section{Pre-publication history}

The pre-publication history for this paper can be accessed here:

http://www.biomedcentral.com/1471-2350/6/3/prepub

Publish with Bio Med Central and every scientist can read your work free of charge

"BioMed Central will be the most significant development for disseminating the results of biomedical research in our lifetime. "

Sir Paul Nurse, Cancer Research UK

Your research papers will be:

- available free of charge to the entire biomedical community

- peer reviewed and published immediately upon acceptance

- cited in PubMed and archived on PubMed Central

- yours - you keep the copyright

Submit your manuscript here:

http://www.biomedcentral.com/info/publishing_adv.asp
BioMedcentral 